\title{
Conflictual Diversity and Contested Cultural Heritage: Newspaper Coverage of Religion in Norway 1938-2018
}

\author{
KNUT LUNDBY \\ University of Oslo
}

\begin{abstract}
The visibility and diversity of religion in selected Norwegian newspapers published in the capital of Oslo is studied in a quantitative analysis at ten-year intervals from 1938 to 2018, with an emphasis on the last forty years. Recent structural transformations in the newspaper industry and editorial choices cut the number of articles on religion considerably in 2018 compared to earlier years. However, the relative visibility of religion in the share of the total editorial output is fairly stable, at about 1.5 per cent of the content. Rather, the changes have been with the diversity and criticism of religion. The representation of Islam has strongly increased, while the newspapers have played down the coverage of the Lutheran majority church. The conflictual diversity and contested cultural heritage in the newspaper material are partly shaped by the media dynamics in the mediatization of religion.
\end{abstract}

Keywords: Norway, newspapers, visibility of religion, mediatization, diversity

This article aims to trace and discuss changes in the coverage of religion in the main Norwegian newspapers at selected intervals from 1938 to 2018. Changing newspaper coverage is studied especially in terms of the visibility and diversity of religion, with an eye on its contestation.

The 'visibility of religion' is simply taken as the presence of religion in the media and other public arenas, as opposed to invisibility and absence. Diversity in the study is opposed to homogeneity (Taira 2019a).

This is not an historical account. Rather, the approach is one of media sociology, highlighting changes in newspaper tone and topics within the transformations of the media structure and the religious landscape in Norway.

Following brief outlines of how the media landscape and the religious landscape in Norway have evolved, the article sketches the newspaper coverage of religion from 1938 to 1978. The main part, however, concentrates on the forty years from 1978 to 2018. 


\section{The changing media landscape in Norway}

In the context of the similarities of the Nordic media system (Taira 2019a; Lundby et al. 2018; Syvertsen et al. 2014) Norway has a decentralized newspaper structure. The focus on the daily press in this study means that many papers have not been considered. Of the 223 titles listed in 2017 in Norway, fifty-one newspapers were published six or seven days a week (Høst 2018).

Unlike radio and TV, newspapers in Norway have always had private or political party owners. They have reflected class and regional distinctions, and opposing political views. Until the 1970s most cities - even smaller ones - had at least two newspapers, related to different political camps, each arguing for its view, even in the choice of topics and perspectives in news coverage. From the end of the 1970s this 'party press' evolved into a more independent press engaged in market competition. Although they preserved a political-ideological stand for their editorial opinions, most papers covered different and opposing views in their journalism. The introduction of television forced newspapers to take a broader, non-partisan perspective (Bastiansen 2006; 2009). Television came late to Norway, being introduced as a regular public service in 1960.

The Norwegian Broadcasting Corporation, NRK, is expected by parliament to cover religious life in the country. However, this was not stated explicitly until the first 'NRK placard' was issued by Stortinget in 2007. Previous Director Generals of NRK had themselves found reasons to transmit worship from churches and allow Christian preachers to deliver devotions, primarily on the main radio channel and sometimes on television (Lundby 2016).

From the 1980s the newspaper industry was consolidated in a series of mergers and new constellations as part of the transformation of the Norwegian media system. This was further ignited by digitalization from the latter half of the 1990s (Bastiansen and Dahl 2019, Ch. 8). The first newspaper in Norway to offer an online version was a local up-North paper in 1995. This was only two years after the launch of the first web browser made the internet available for information searches. Despite the changes in the newspaper industry, there has been remarkable stability in the number of papers, largely due to the Norwegian press subsidy system, which has operated since 1969. The share of newspaper readers has declined and has only partly been reflected in the rise of digital forms (Høst 2018). Digital news distribution has developed on the basis of the established print media, with publishing houses developing diversified online strategies (Slaatta 2015).

Especially during the last decade the newspaper industry in Norway, as 
elsewhere, has endured drastic downscaling. Journalists have been laid off, and newspapers are slimmer. Global players in the new 'platform society' (van Dijck et al. 2018) like Facebook and Google have taken the steam out of the advertising economy of the national and local press. Furthermore, subscription income has declined because of the switch to digital news coverage and changing user habits, especially among younger generations. As will be shown, this transformation of the Norwegian newspaper industry has affected the coverage of religion.

\section{The changing religious landscape in Norway}

The search for 'religion' in the daily press allows us to observe how private and institutional forms and expressions of faith and spirituality appear in writing and images in newspapers as public arenas. The newspaper coverage shows only fragments of religious life and power structures. The press must select what to represent. Through framing (Entmann 1993) and formatting (Lundby 2019) editors and journalists shape a particular public perspective on religion. In its exposure over time to media dynamics, religion as a social and cultural phenomenon may itself change. This is accounted for in theories on the mediatization of religion (Taira 2019a; Hjarvard and Lundby 2018; Lundby 2018b; Lövheim and Lied 2018; Hjarvard and Lövheim 2012).

In parallel with the breaking of the monopoly and intensified market competition in the media sphere since the early 1980s, the diversity of the religious landscape has increased. At the end of the 1970s Norway experienced the first widely organized public initiatives to encourage people to leave the dominant Lutheran state church, and the first influx of Muslim immigrants. There had been a plurality of Christian denominations before, but diversity slowly became more visible with the growth of Islamic congregations and the secular humanist association.

No single theory of the sociology of religion - whether it concerns secularization, de-secularization, or post-secularity - has catered for the transformations of the religious landscape in the Nordic countries in recent decades. Rather, changes should be understood through the meta-theoretical concept of religious complexity, in which multiple religious trends that may even seem inconsistent simultaneously coexist. The concept implies relationships between different levels in empirical analyses, reciprocity between modernization and secularization, and openings for sudden and non-linear social change (Furseth 2018). A study of religion in the Nordic 
media sphere reveals religious complexity since the 1980 s, to which various media have contributed (Furseth et al. 2019).

Religion has always been contested, but alternative minority voices have not easily been heard in the public sphere. A study of religious change in the Nordic region from 1930 to 1980 (Gustafsson 1985; 1987) found it possible to 'speak of a common religious culture in the five Nordic countries' centred on the similar 'folk churches', i.e. Lutheran majority churches (Gustafsson $1987,180)$. However, the forms of state church differ. Norway changed its constitution in 2012, with a further dissolution of the link between church and state in 2017.

In summarizing the 1930-1980 project, Göran Gustafsson indicated that 'factors external to the religious culture and the churches' organizational forms' were as 'important in determining religious activity' (Gustafsson $1987,180)$. He pointed to the position of religion in the mass media as the crucial factor (Gustafsson 1985, 263).

\section{The first forty years (1938-1978)}

The forty years from 1938 to 1978 must be mentioned briefly because of the limited empirical studies of religion-related media content in Norwegian newspapers. This period was dominated by the party press and the Lutheran state church, with the exception of the Second World War years.

The political tension before the war was between a liberal-conservative base, the rise of agrarian fascism, and emerging social democracy. The church tended to be conservative. Its opposition to the Nazi government and occupation strengthened its position in the years immediately after the war. The social democrats took the political lead in a period of political stability and toned down their previously critical stance towards the church and religion, finding the control afforded by the state church useful. Religious controversies received more attention in the press from the end of the 1970s. The party press structure was by then also beginning to loosen.

The study of religious change in the Nordic countries applied indicators for the selected years 1938, 1958, and 1978 (Gustafsson 1985; 1987), summarizing tendencies in 'Religion in mass media' in Norway (Lundby 1985, 188-189). Religion-related media content in four newspapers before Easter and Christmas was studied: the conservative Aftenposten, the social democratic Arbeiderbladet, the cultural-liberal Dagbladet - all published in the capital - and the regional paper Stavanger Aftenblad, with a liberalconservative base. 
There were more marked differences between the papers than between the selected years regarding the extent and content of the coverage of religion. The conservative paper from the capital and the regional paper both presented religion on the terms set by the dominant Lutheran state church, with respect for the authority of the church. The cultural-liberal paper was characterized primarily by the paucity of its pieces on religion or in its interpreting of religion in accordance with its own set of cultural codes. Its representation of Christianity was largely critical of the church or in connection with the arts. The social democratic paper lacked any considerable coverage of religion (but there was more in 1958 and in 1978 than in 1938). This paper emphasized the social and political aspects of Christianity, partly in a rewriting of church tradition as concurrent with its own.

Despite the differences, all four newspapers focused considerably more on Christianity in all three periods. In 1958 there was no coverage of other religions at all in the papers published in the capital. In 1938 and 1978 there was some, but more by chance and usually considered on the terms set by the dominant church. Material on other spiritual issues attracted little interest in all four papers. The differences between them stemmed rather from the angle they applied to Christianity.

The three papers from the capital were close in the profile they gave to religion from 1938 through 1958 to 1978, with Christianity becoming a more controversial topic in Aftenposten in 1978. Aftenposten still then treated Christianity institutionally, but placed more emphasis on private and individual religious expression. Compared with 1958, by 1978 Aftenposten was also moving from an unambiguously conservative to a liberal position in its coverage of the church and religion. The convergence on religion between the capital's papers also appeared to shift in the opposite direction, with Arbeiderbladet and Dagbladet being more institutional in their treatment of Christianity in 1978. Their criticism of Christianity was directed more than it had been towards the church rather than individuals or on the basis of theology.

The visibility of religion in columns was lower in Arbeiderbladet and Dagbladet than in Aftemposten and Stavanger Aftenblad. We have no figures to compare visibility across the selected years. The diversity of religion-related material was certainly limited in all four papers during this period. Despite the emerging controversies and critical tendencies in the representation of religion, the frame was still set by Christianity and the state church. 


\section{Media dynamics with contested religion}

Religious diversity in society and in press coverage increased during the following forty years. This was researched by another group of Nordic scholars in the NOREL project on 'The role of religion in the public sphere' (Furseth 2018). Immigration 'changed the Nordic ethnic and religious landscapes and especially transformed Sweden, Norway, and Denmark into relatively diverse nations' (Furseth 2018, 3). With the social and political tensions associated with multiculturalism and immigration religion was more contested, which the press covered according to the dominant news values, with controversy and conflict being prominent news criteria (Harcup and O'Neill 2017).

Paradoxically in Norway, as in the other Nordic countries, widely held secular attitudes in the population and shifts towards a more secular state are combined with a persistence in membership of the majority church and its position in society (Taira 2019a). Christianity, especially as represented by the Church of Norway, appears as part of the country's cultural heritage. Until 2012 the constitution stated that 'the Evangelical Lutheran religion shall remain the official religion of the State'. The new formulation said that 'Our values will remain our Christian and humanist heritage'. Use of the term 'our' denotes a national imagined community (Anderson 1991), which may be in tension with a diverse and secular society.

The two scholars of religion, Cora Alexa Døving and Siv Ellen Kraft, observed new usages of 'the Christian cultural heritage' from the later 1990s, linked to being Norwegian and with an edge towards immigrant cultures. Similar changes took place in the Danish and Finnish media (Christensen 2019; Taira 2019b). In Norway Christianity began to be connected with nationality in political debate, and this was often played out in the news media, online commentary fields, and in social media. Being Christian was now related to culture instead of religion. 'Christian heritage' began to be argued from a different political position - most recently, prominent in the populist right-wing discourse (Døving and Kraft 2013, 75-99). The 'Christian heritage' discourse was intended to be inclusive but came to be exclusive of minorities. It was intended to encompass different positions and identities, but became contentious.

Religion has become contested. A range of case studies of such cultural tensions in Scandinavia points to the media dynamics involved in the contestation (Lundby 2018a). Mass media and social media make 'a communicative environment providing a horizon of orientation for citizens about conflicts relating to religion, and provide social actors with the tools to engage in such conflicts' (Hjarvard and Lundby 2018, 51). Three differ- 
ent media dynamics operate. First, the media has an ability to amplify an event or a comment. Second, it frames the part of the world it represents and gives space to the performative agency of involved actors. Third, the media co-structure communication and action through the social and communicative environment of which they are part (Hjarvard et al. 2015). These are dynamics in the mediatization processes, in this case on contested religion, thereby partly shaping the aspects of religion at issue.

\section{The last forty years (1978-2018): data and methods}

The remaining part of the article focuses on the period since 1978, mainly with reference to the NOREL newspaper data from 1988, 1998, and 2008 (Furseth 2018, 327ff.; Lundby et al. 2018). A similar dataset on Norwegian newspapers in 2018 is added as an update. The actual data for empirical study has had to be selected and is thus limited. The conclusions are primarily based on quantitative content analyses of a few significant weeks throughout the year. Within the decentralized Norwegian newspaper structure this article confines itself to daily papers published in the capital. They are in part nationally distributed but naturally do not afford a full picture of the Norwegian daily press. To make comparisons across time, the article confines its focus to the print media. The reading undertaken digitally for this research is from the classical print media. This study does not, therefore, tackle the new digital newspaper forms. Despite these limitations, the study still offers a systematic analysis of newspaper coverage of religion in Norway.

The criterion to be regarded as an article on 'religion' is the explicit use of this term or the prominent expression in the article of the name of a world religion (e.g. Islam, Buddhism), a confession within a specific tradition (e.g. Lutheran, Catholic), a religious authority role (e.g. bishop, imam), a religious building (e.g. church, synagogue), other religious symbols (e.g. cross, hijab), and religious or spiritual practice. Thus, New Age and other new religious movements are included, as are atheism and life-view organizations when they appear as anti-religion. Articles may take a positive as well as a critical approach to religion and its role in society.

The NOREL study continues the content analyses of Aftenposten and Stavanger Aftenblad from the 1930-1980 research. The same applies to Arbeiderbladet, which changed its name to Dagsavisen in 1997. Instead of Dagbladet another tabloid, VG, was included. The methodology and results of the Norwegian part of the NOREL newspaper study has been reported elsewhere (Lundby et al. 2018; Lundby and Gresaker 2015; Lövheim and Lundby 2013). 
This article presents a further comparison with the new data from 2018. As for the previous years, four two-week periods are selected: before Easter and before Christmas; before the end of Ramadan; and two weeks from a non-festive period in October. The coding is based on reading full-page newspapers, thus avoiding pitfalls with database searches for keywords (Linderman and Lövheim 2016).

The comparison focuses on the three newspapers published in the capital of Oslo whose journalism is of a secular nature (Døving and Kraft 2013). The selected papers are located in different ownership structures and cultivate different readership cultures (de Cheveigné and Veron 1997; Lövheim and Lundby 2013). Aftenposten and VG are both owned by Schibsted Media Group. The former relates to a middle-class readership in the wider Oslo area, while $V G$ is a popular nationally distributed tabloid. Arbeiderbladet was owned by the Labour Party until 1991. Under its new name, Dagsavisen, the paper became an independent business, still cultivating a working-class and social democratic readership.

The quantitative content analyses distinguish between large and smaller articles, religion as a dominant and less central theme, religion represented in different genres, and reference to various religious traditions. A further more qualitative reading of selected articles is undertaken on large or medium-sized news pieces and features on religion from each of the two regular October weeks of the selected four years. These 140 articles are examined in terms of visibility and diversity of religion, and also of globality, individuality, public utility, and dominant voice (Taira 2019a).

The analyses of the Norwegian newspapers by Lövheim and Lundby (2013) recalculated the number of articles into indices, where those with religion as the main topic were given twice the value of articles in which religion was a less significant theme. This method emphasized visibility in terms of the prominence of religion in the article, whether it was a sizeable entry or a small paragraph. However, the use of such indices would complicate the argument here. The unit of analyses in the following is therefore the actual number of articles.

\section{Decreased visibility?}

The term 'visibility of religion' contains many theoretical features, especially in connection with propositions of a 'resurgence' of religion (Furseth et al. 2019; Taira 2019a; Hjelm 2015a), to be discussed in the concluding parts of this article. 
At first glance there is a radical downturn in 2018 in the number of religion-related articles in the three Norwegian newspapers compared to the previous ten, twenty, and thirty years (see Table 1). There thus seems to be a sharp decrease in the visibility of religion.

Table 1. Visibility: Number of articles on religion in the four two-week periods each year

\begin{tabular}{rrrrrr}
\hline & 1988 & 1998 & 2008 & 2018 & All \\
\hline Aftenposten & 123 & 163 & 130 & 74 & 490 \\
Arb.bl./Dagsavisen & 62 & 95 & 90 & 28 & 275 \\
$V G$ & 65 & 136 & 91 & 62 & 354 \\
All & 250 & 394 & 311 & 164 & 1119 \\
\hline
\end{tabular}

Table 2. Absolute and relative visibility of religion in paper editions during the four researched two-week periods 1988, 1998, 2008, and 2018. Number of articles with percentages.

\begin{tabular}{|c|c|c|c|c|c|}
\hline & 1988 & 1998 & 2008 & 2018 & All \\
\hline Aftenposten & & & & & \\
\hline -total editorial output & 9659 & 11908 & 12284 & 4246 & 38097 \\
\hline -articles on religion & 123 & 163 & 130 & 74 & 490 \\
\hline -percentage on religion & $1.3 \%$ & $1.4 \%$ & $1.1 \%$ & $1.7 \%$ & $1.3 \%$ \\
\hline \multicolumn{6}{|l|}{ Dagsavisen } \\
\hline -total editorial output & NA & NA & 2115 & 5353 & 7468 \\
\hline -articles on religion & [62] & [95] & 90 & 28 & 118 \\
\hline -percentage on religion & -- & -- & $4.3 \%$ & $0.5 \%$ & $1.6 \%$ \\
\hline \multicolumn{6}{|l|}{$V G$} \\
\hline -total editorial output & 3684 & 3917 & 9254 & 3699 & 20554 \\
\hline -articles on religion & 65 & 136 & 91 & 62 & 354 \\
\hline -percentage on religion & $1.8 \%$ & $3.5 \%$ & $1.0 \%$ & $1.7 \%$ & $1.7 \%$ \\
\hline \multicolumn{6}{|l|}{ All papers } \\
\hline -total editorial output & 13343 & 15825 & 23653 & 13298 & 66119 \\
\hline -articles on religion & 188 & 299 & 311 & 164 & 962 \\
\hline -percentage on religion & $1.4 \%$ & $1.9 \%$ & $1.3 \%$ & $1.2 \%$ & $1.5 \%$ \\
\hline
\end{tabular}

Note: The total editorial output is calculated by searching the Retriever (Atekst) database, searching for the common terms, in translation: 'and' or ' $a$ ' or 'on', because one of these words is expected to appear in almost all articles. Compared to Lundby and Gresaker (2015; Table 3.6), there must have been a previous miscalculation of the total output in $V G$ in 2008. The present table is based on a new, updated search. NA = data not available. 
However, the picture changes when the restructuring of the newspaper industry is taken into account. The reductions in pages and journalistic staff caused by the rise of online news and the loss of advertising revenue to global platform companies have influenced the number of articles on religion, as on other topics. Estimating the total paper output of editorial material in each publication during the four researched periods each year allowed the share of articles on religion to be identified. There is thus an absolute visibility concerning the number of actual articles on religion and a relative visibility concerning the percentage of articles on religion of the total output. The totality of editorial material in a period was found by a search for one or more of the words 'and' or 'a' or 'on', assuming this would catch almost every article, regardless of topic.

The picture is not uniform. While the two Schibsted-owned papers, Aftenposten and VG, had severely cut their editorial stuff by 2018 compared to 2008, Dagsavisen had doubled its number of editorial pieces. Their share of articles on religion, however, was much higher in 2008 than ten years later, despite the lower editorial total, an indication of editorial choice. Absolute visibility fell from ninety to twenty-eight articles on religion, while the relative visibility in Dagsavisen fell from 4.3 per cent to 0.5 per cent. This is the lowest share in Table 2. Regardless of the much lower absolute visibility of religion in Aftenposten and VG between 2008 and 2018 , the relative visibility in these two Schibsted papers actually rose to 1.7 percent of the total output.

Across the four selected years, $V G$ has the highest relative visibility of religion, with 1.7 per cent of its total editorial output. For the three papers together, 1998 was the peak, with 1.9 per cent of all articles on religion. The share went down to 1.3 per cent in 2008 and to 1.2 per cent in 2018. On average, 1.5 per cent of the editorial material was on religion, which is similar to the share for NRK, the public service broadcaster (Lundby and Gresaker 2015, note 5).

The cutbacks in journalistic resources and new layout norms may result in articles that take up more space, usually with larger photographs. This seems to be the case with Aftenposten. In 1988 nearly a third of the entries on religion in this paper were large articles over three or more columns. In 2008 and 2018 this was the case with two-thirds of such articles. Dagsavisen and $V G$ has had a more stable share of large articles, with about half the entries in all four selected years. In 2018 Dagsavisen had more medium-sized articles on religion than before, while the portion of medium-sized entries went down in Aftenposten and VG. 
The other side of this coin is the share of small pieces or paragraphs. Of the small total of 164 articles on religion in 2018, more than a quarter were this size. When papers are short of their own resources, they may also turn to condensed messages from the national news agency, NTB. Forty-three of the 164 articles in 2018 originated at NTB (27 per cent), appearing in the papers either as medium-sized or small pieces.

The changes in visibility thus reveal another aspect of the complexity of religion: in relative terms, the share of articles on religion may even be higher than before. But the absolute number of such articles is shrinking, primarily due to cuts in the newspaper houses. Religion as a topic is thus less visible in the paper versions of newspapers. Is the diminished presence of religion in the traditional print media countered by its visibility in online news, in social media, and in public service and commercial broadcast media, with their linear and streaming output in radio, television, and online services? Possibly not - but we do not know.

\section{In which newspaper genres is religion visible?}

Religious columns, i.e. articles of Christian proclamation or reflections by invited writers under separate headings, have disappeared over the years. Until the turn of the millennium many main newspapers carried daily or weekly Christian reflections in special columns. These comprised 5 per cent of all articles on religion in the three capital newspapers in 1988 . Ten years later the share was down to 3 per cent, and in 2008 it was 2 per cent. In 2018 none of the three papers carried such columns.

The average share of editorials has been under 3 per cent of the articles on religion. Of the five registered editorials in 2018, only one was of a significant nature: VG going against the ban on face-coverings. The other four were merely very short, ironic 'second-editorials', a tendency also noted by Lövheim and Linderman (2015) in their study of Swedish editorials. In the Norwegian papers the editors today do not readily adopt an open position on religious issues. This seems not to be the case in Finland and Sweden (Taira 2019b; Lövheim 2019). Are the Norwegian editors avoiding conflict with their readership, or do they think religion has become irrelevant? Neither seems to be the case where news and debate pieces on Islam are concerned, as shown below.

While the papers avoid taking a stand on religion in editorials, the share of debate pieces on these issues is growing, as in Denmark (Christensen 2019). The growth in the Norwegian papers was from 8 per cent in 1988 
to 23 per cent in 2018. In this sense, religious controversies have become more visible in the columns. News makes up the biggest share of articles on religion, but this is still down from 67 per cent in 1988 to 61 per cent in 2018. Larger features on religion were stable at 18 per cent in the three first selected years, dropping to 13 per cent in 2018.

In the second coding of the main and medium-sized Norwegian news articles and features from the two October weeks, religion tends to be presented as public (61 per cent of the 140 articles across the four selected years) rather than private (39 per cent, including internal church issues). The tabloid $V G$, however, has a fifty-fifty split between the public and private aspects of religion in its articles.

\section{Increased diversity}

The increased diversity in the coverage of religion in the selected newspapers reflects to some extent the increased diversity of Norwegian society, though the diversity of the coverage may not entirely reflect the societal trend. News is always edited.

The most remarkable trend is the increasing attention paid to Islam and the declining coverage of the Lutheran majority church, as in the other Nordic countries (Christensen 2019; Lövheim 2019; Taira 2019b). In Norway in 1988 the Lutheran majority tradition was covered in 62 per cent of the articles, while Islam accounted for 3 per cent. In 2018 Islam was the subject of 27 per cent of the articles, while the majority Lutheran church accounted for no more than 21 per cent. In 2018 the three capital papers evinced an interest in other forms of Christianity, which was a new trend (see Table 3).

Table 3. Diversity: Articles on religious traditions in the four two-week periods in percentages.

\begin{tabular}{rrrrrr}
\hline & 1988 & 1998 & 2008 & 2018 & All \\
\hline Lutheran majority & 61.6 & 57.4 & 33.1 & 20.7 & 46.2 \\
Other Christianity & 22.4 & 20.6 & 19.9 & 34.8 & 22.9 \\
Islam & 2.8 & 11.4 & 19.6 & 27.4 & 14.1 \\
Other world religions & 1.6 & 2.8 & 8.0 & 5.5 & 4.4 \\
Non-institutional & 4.0 & 4.6 & 5.1 & 6.1 & 4.8 \\
Religious criticism & 0 & 0.3 & 2.6 & 3.7 & 1.3 \\
Unclassifiable & 7.6 & 3.0 & 11.6 & 1.8 & 6.3 \\
Total & $100 \%$ & $100 \%$ & $100 \%$ & $100 \%$ & $100 \%$ \\
$(\mathrm{~N})$ & $(250)$ & $(394)$ & $(311)$ & $(164)$ & $(1119)$ \\
\hline
\end{tabular}


The coding for the other categories may be less certain because of the small numbers and the less clear criteria for catching them. World religions other than Islam and Christianity show a slight increase. As with noninstitutional forms of religion, the average is just under 5 per cent of the articles. Religious criticism has become more visible but still constitutes only a small portion of the articles. However, such entries may easily have been overlooked. Unclassifiable articles had a much larger share (12 per cent) in 2008 compared to the other selected years, which may in part be due to coding uncertainty.

The media observer Retriever found that Islam was mentioned in $V G$ ten times as often as Christianity in 2015. Islam did not become a topic in the Norwegian media until after the 1979 revolution in Iran (Michelsen 2016). A study across all Norwegian editorial media in 2016 showed that Islam and Muslims were mentioned more times than any crisis or debate that year (Retriever 2017).

One might expect that newspaper articles on religion before the great religious festivals would at least to some extent be related to the upcoming holidays: Easter, Christmas, and Ramadan before the breaking of the fast at Eid. However, this is only true to a limited extent. Although there is a larger share of religion-related articles before Easter and Christmas than before Eid or in the two October weeks, only a few relate to the Christian celebration. In 2018 this was the case with only four of the thirty-six articles; two were columns by bishops. Before Christmas seven of the thirty-nine articles were related to the specific Christian tradition. More articles were published in the two weeks before Eid than before Easter or Christmas, but only two concerned Ramadan: a photo in $V G$ of Muslims in Malaysia 'looking forward to eating', and a debate piece in Aftenposten arguing against the irrational nature of Ramadan by a leading politician. (During and after the celebration of Eid there were three further articles).

The more detailed coding of large and medium-sized news and feature articles in the regular October weeks sought to identify whether religion was represented as part of a diverse and pluralist society or as a continuation of a dominant tradition. The outcome was mixed. Through the four time-cuts Aftenposten and VG carried as many articles about the Lutheran former state church as they did about a pluralist society. Arbeiderbladet/Dagsavisen leant more towards diversity. 


\section{The other key variables}

The other key variables presented by Taira (2019a) were included in the second coding of the October weeks in 2018. These aspects tend towards a domestic, institutional, and collective perspective of religion in the three newspapers, which are also considered to a large extent a public utility. These variables are:

Globality as opposed to locality: All three papers tended to pay more attention to religion in the national, regional, or local contexts than to religion at the global or international level.

Individuality and choice as opposed to collectivity: As one would expect, all three papers clearly tended to represent religion as a collective and under a wider obligation, and less as individual expressions. Newspapers tend to focus on the institutional settings where power lies, but non-institutional religion has become somewhat more visible (cf. Table 3).

Public utility: Is religion considered useful for society and the public good, or is it represented as a self-enclosed institution, something in itself? In most articles this was not touched on, but when visible the coverage leant towards religion as a public good. This included implied public utility (e.g. in relation to the royal family). Religion as something in itself includes the church's internal issues.

Voice: Which voice(s) on religion is/are prominent in the articles? Over the years Aftenposten has tended towards institutional voices, while Arbeiderbladet/Dagsavisen has included a greater number of other voices, including those of journalists.

\section{Two discursive shifts}

The coding categories do not grasp all the nuances, but some key discursive shifts emerge. Two trends stand out.

First, over the selected years from 1988 to 2018 the part of Norwegian cultural heritage related to the majority Lutheran church tradition has become visibly contested, and this is reflected in the three capital newspapers. Limited open conflict and criticism, with secularist or anti-religious voices, are present. Identified religious criticism increased to about 4 per cent of the articles in 2018. Most concerned the institutional aspects of religion, but the Lutheran majority tradition has become considerably less visible. The newspapers rarely contest the church in their editorials, as in Finland (Taira 2019b) but contrary to Sweden (Lövheim 2019). The Norwegian capital 
newspapers simply leave the old church behind, by discontinuing religious columns, and providing more modest news coverage of the majority tradition (down from 61 per cent in 1988 to 21 per cent in 2018 of all the collected news articles) and less debate on the Church of Norway (down from 53 per cent in 1988 to 19 per cent in 2018 of all debate entries). Other forms of Christianity, however, were made more visible in the news and less controversial in debate articles than the share of articles on Christian communities outside the former state church. To the extent that the Lutheran majority tradition is contested in the three newspapers, this is primarily by making it less visible than its share of the population (still 70 per cent in 2018). A closer textual analysis might confirm the discursive shift to a nationalist agenda in the use of the 'Christian cultural heritage' that Døving and Kraft (2013) identified. A clear voice on behalf of Christian communities must to a great extent be given by representatives of these churches themselves, and thus mostly in columns or debate pieces. This resembles what Norwegian news editors told Anders Firing Lunde in his study of their preparedness to cover Islamic practice: 'It's up to the Muslims to take initiatives' (Lunde 2013).

Second, Norway's increasing cultural and religious diversity has become visible in newspaper coverage. The main trend is in the growth in news and commentaries concerning Islam and the presence of Muslims in society. Unlike its coverage of the Church of Norway, the newspaper's focus on Islam and Muslims goes well beyond the proportion of Muslims in Norway. While Norway's population may have been 4 per cent Muslim in 2016 (Østby and Dalgard 2017), the share of articles on Islam and Muslims in the three selected newspapers was five to seven times higher (see Table 3). Much of the coverage was about jihadist movements in other parts of the world, comprising half the articles on Islam and Muslims in all main newspapers in Norway in 2016. Sixty per cent of this foreign news was about Islamic terrorism, IS, foreign fighters, or radical Islam (Retriever 2017). The increased coverage of Islam and Muslims in the three capital papers leans towards debate pieces rather than news, as in Denmark (Christensen 2019). In 1988 this was the case with 5 per cent of all debate pieces in the three Oslo papers, while the share had risen to 38 per cent in 2018. This was in line with Retriever's study of all editorial media, showing that domestic features on Islam and Muslims tended to be debate pieces; the foreign material referred rather to what happened. In sixteen per cent of all articles on Islam and Muslims in a Norwegian context the most prominent theme was criticism of Islam. However, there were as many debate pieces countering criticism of Islam as there were articles contesting it (Retriever 2017). In the three capital newspapers few editorials addressed 
Islam, but in general the representations of Islam and Muslims were more openly conflictual than they were in their representations of Christianity.

\section{Religion in political conflict}

Two conflicts were prominent in the daily press in Norway during the two surveyed weeks in October 2018, one international and one national. The former was the Khashoggi case, when a dissident Saudi Arabian journalist was murdered in the Saudi embassy in Istanbul. The latter was the conflict in the Christian Democratic Party in Norway concerning whether to join a 'red' or 'blue' government.

None of these conflicts was grasped by this study's coding instrument, except when contenders in the Norwegian case were characterized by their Christian faith. Both cases afford good examples of deeper religious controversies or conflicts lying behind the political surface. In international diplomacy and media coverage the Khashoggi case was fed by the underlying conflict between Sunnis in Turkey and Salafists in Saudi Arabia. Behind the media reports on Kristelig Folkeparti's choice of political alliance lies a deeper understanding of how 'Christian values' can be realized in society. This conflict is connected with the debate about the 'Christian cultural heritage', but it is not fully reflected in the data because of the study's coding criteria. Cultural contestations covered by the media as political conflicts may often have their roots in contested religion.

The present quest for visibility fails to capture such deeper references to religion in the political realm. The same concerns the use of metaphor with reference to contested religion in the editorial material. This is not included in the coding, because the articles here should be explicitly connected with religion. Indeed, Lövheim and Linderman included such metaphors in their study of Swedish editorials. They concluded 'that these references to religion through mediatization are used in a way where their meaning becomes detached from institutional or dogmatic religious authority' (Lövheim and Linderman 2015, 43).

\section{How to interpret the visibility of religion}

A critical discourse analysis such as the one concerning editorial material in Swedish newspapers (Lövheim 2017) would have afforded a much richer base for the interpretation of the visibility of religion. However, what can be learnt from the available quantitative material? 
First, visibility as the presence of religion in the media should not be confused with the influence of religion in society (Hjelm 2015a). We 'cannot assume a direct relation between changes in the visibility of religion in the media and changes in the role of religion in public discourse' or in the public sphere (Lövheim and Linderman 2015, 32, 44). It may in fact be that an increase in references in the daily press is the result of religion becoming more controversial than it previously was (Lundby 2018a). Neither can one draw any conclusion on people's religious life and practice from the coverage of religion in the newspapers. 'The complexity frame of reference reminds us that one cannot reduce from a public presence to individual religiosity. The latter points to the significance of religion for individuals, while the former shows the public presence of religion as a topic, either in a descriptive way or because it is valued or contested' (Furseth et al. 2019, 76).

Second, the interpretation is based on theories in the sociology of religion concerning the changing religious landscape. Titus Hjelm (2015b) suggests that religion could be used by governments or public authorities as a resource for policies to combat social problems and to support the welfare state. However, in secular newspapers with conflict-oriented news criteria the opposite approach, which regards religion as a social problem, may dominate, as diversity increases with immigration, and the coverage of traditional church institutions becomes more critical over time. In any case, Hjelm argues, it is the social contribution of religions rather than faith that is being valorized. There is an 'internal secularization of discourse' at work in the new visibility of religion (Hjelm 2015b, 15). To grasp the changes behind the visibility, one needs insights into the complexity of religion.

Third, changes in the visibility or presence of religion in the daily press depends largely on structural changes in the newspaper industry. The distinction between the absolute and relative visibility of religion testifies to this. Changes in newspapers occur within a larger transformation of the media landscape. The party press in Norway dissolved towards the end of the 1970s, largely because of the encroaching power of television. The print media is challenged by online forms. The editorial media today must relate to the debates in social media, and in general to audiences and users who themselves produce content. The viability of national, regional, and local newspapers is threatened by the loss of revenue to global network giants like Facebook and Google. The relationship between all these transformations in the media landscape and social and cultural change is captured by the concept of mediatization (Hepp et al. 2010). The representation of religion in the media depends on the structural changes in the media industry and 
thus on the general processes of mediatization. In the day-to-day newspaper business the mediatization of religion is shaped over time by editorial formatting and media dynamics.

\section{Conclusion}

When structural change in the newspapers is taken into account by looking at the visibility relative to the total output of editorial material, the presence of religion is relatively constant between 1988, 1998, 2008, and 2018. There has been some variation between the three Oslo-based newspapers over the years, but overall there is stability, with about 1.5 per cent of the total output. However, the mediatization of religion remains effective: the downsizing of newspapers combined with editorial choice results in media users finding less to read about religion than previously. Editorial gatekeeping and formatting become even more important. However, with less to read about religion in the newspapers, a larger share of the media's religious coverage may be found in social media echo chambers, contributing to a transformed societal religious horizon.

The secular newspapers' coverage exaggerates the extended or increased diversity of religion and criticism of religion in the eighty-year period, and in particular during the last twenty to thirty years. The growing Muslim presence in Norway, and terrorism and violence in other parts of the world connected with forms of Islam, is certainly of news interest, but its coverage is out of proportion with the country's Muslim minority. In contrast, the Church of Norway, which remains a majority religious institution, is covered with considerably less interest than previously, and less than its recent share of the population might suggest is warranted. Editors are not obliged to adjust the coverage to the various groups in Norway, but with their skewed coverage the newspapers contribute to a general mediatization of the perceived role of religion in society. Conflictual aspects of increased diversity - and especially of Islam - are placed to the fore, while the print media downplays the more contested cultural heritage of the majority church.

\section{$* * *$}

KNUT LUNDBY is Professor Emeritus of Media and Communication, University of Oslo. E-mail: knut.lundby@media.uio.no 
Bibliography

\section{Anderson, Benedict}

1991 Imagined Communities. London: Verso.

Bastiansen, Henrik G.

2006 Da avisene møtte TV. Partipressen, politikken og fjernsynet 1960-1972. Dr.art. thesis, Universitetet i Oslo.

2009 Lojaliteten som brast. Partipressen i Norge fra senit til fall 1945-2000. Pressehistoriske skrifter nr. 11. Oslo: Norsk pressehistorisk forening.

Bastiansen, Henrik G. and Hans Fredrik Dahl

2019 Norsk mediehistorie. 3rd edition. Oslo: Universitetsforlaget.

\section{Christensen, Henrik Reintoft}

2019 Continuity with the Past and Uncertainty for the Future: Religion in Danish Newspapers 1750-2018. Temenos: Nordic Journal of Comparative Religion 55 (2), 201-24.

de Cheveigné, Suzanne and Eliséo Veron

1997 The Nobel on First Page: The Nobel Physics Prizes in French Newspapers. Public Understanding of Science 3 (3), 135-54.

\section{Døving, Cora Alexa and Siv Ellen Kraft}

2013 Religion i pressen. Oslo: Universitetsforlaget.

\section{Entmann, Robert M.}

1993 Framing: Toward Clarification of a Fractured Paradigm. Journal of Communication 43 (4), 51-8.

\section{Furseth, Inger (ed.)}

2018 Religious Complexity in the Public Sphere: Comparing Nordic Countries. Basingstoke: Palgrave.

Furseth, Inger, Lene Kühle, Knut Lundby, and Mia Lövheim

2019 Religious Complexity in Nordic Public Spheres. Nordic Journal of Religion and Society 32 (1), 71-90.

\section{Gustafsson, Göran (ed.)}

1985 Religiös förändring i Norden 1930-1980. Malmö: Liber.

1987 Religious Change in the Five Scandinavian Countries 1930-1980. Comparative Social Research 10, 145-81.

\section{Harcup, Tony and Deirdre $\mathrm{O}^{\prime}$ Neill}

2017 What is News? Journalism Studies 18 (12), 1470-88.

\section{Hepp, Andreas, Stig Hjarvard, and Knut Lundby}

2010 Mediatization - Empirical perspectives: An Introduction to a Special 
Issue. Communications: The European Journal of Communication Research 35 (3), 223-8.

\section{Hjarvard, Stig and Knut Lundby}

2018 Understanding Media Dynamics. - Knut Lundby (ed.), Contesting Religion: The Media Dynamics of Cultural Conflicts in Scandinavia, 51-64. Berlin: De Gruyter.

\section{Hjarvard, Stig and Mia Lövheim (eds)}

2012 Mediatization and Religion: Nordic Perspectives. Gothenburg: Nordicom.

\section{Hjarvard, Stig, Mette Mortensen, and Mikkel Fugl Eskjær}

2015 Introduction: Three Dynamics of Mediatized Conflicts. - Mikkel Fugl Eskjær, Stig Hjarvard, and Mette Mortensen (eds), The Dynamics of Mediatized Conflicts, 1-27. New York: Peter Lang.

Hjelm, Titus (ed.)

2015a Is God Back? Reconsidering the New Visibility of Religion. London: Bloomsbury.

\section{Hjelm, Titus}

2015b Is God Back? Reconsidering the New Visibility of Religion. - Titus Hjelm (ed.), Is God Back? Reconsidering the New Visibility of Religion, 1-16. London: Bloomsbury.

\section{Høst, Sigurd}

2018 Avisåret 2017. Rapport nr. 86. Volda: Høgskulen i Volda.

\section{Linderman, Alf and Mia Lövheim}

2016 Measuring Resurgence of Religion? Methodological Considerations in a Study of Swedish Editorials. Nordicom Review 37 (Special issue), 101-14.

\section{Lundby, Knut (ed.)}

2018a Contesting Religion: The Media Dynamics of Cultural Conflicts in Scandinavia. Berlin: De Gruyter.

\section{Lundby, Knut}

1985 Norge. - Göran Gustafsson (ed.), Religiös förändring i Norden 19301980, 154-95. Malmö: Liber.

2016 Mediatization and Secularization: Transformations of Public Service Institutions - The Case of Norway. Media, Culture $\mathcal{E}$ Society 38 (2), 28-36.

2018b Interaction Dynamics in Theory on Mediatization of Religion. - Knut Lundby (ed.), Contesting Religion: The Media Dynamics of Cultural Conflicts in Scandinavia, 299-313. Berlin: De Gruyter.

2018c Introduction: Religion and Media in Cultural Conflicts. - Knut Lundby (ed.), Contesting Religion: The Media Dynamics of Cultural Conflicts in Scandinavia, 3-9. Berlin: De Gruyter. 
2019 Media Formatting Religion and Conflict. - Marius Timmann Mjaaland (ed.), Formatting Religion: Across Politics, Education, Media, and Law, 107-26. London: Routledge.

Lundby, Knut, Henrik Reintoft Christensen, Ann Kristin Gresaker, Mia Lövheim, Kati Niemelä, Sofia Sjö, Marcus Moberg, and Árni Svanur Daníelsson

2018 Religion and the Media: Continuity, Complexity and Mediatization. Inger Furseth (ed.), Religious Complexity in the Public Sphere: Comparing Nordic Countries, 193-249. Basingstoke: Palgrave.

\section{Lundby, Knut and Ann Kristin Gresaker}

2015 Religion i mediene - omstridt og oversett? - Inger Furseth (ed.), Religionens tilbakekomst i offentligheten? Religion, politikk, medier, stat og sivilsamfunn i Norge siden 1980-tallet, 69-104. Oslo: Universitetsforlaget.

\section{Lunde, Anders Firing}

2013 Det er opp til muslimene. Redaksjonelle ledere om islam i den norske offentligheten. Master thesis. Oslo: Universitetet i Oslo.

\section{Lövheim, Mia}

2017 Religion, Mediatization, and 'Complementary Learning Processes' in Swedish Editorials. Journal of Religion in Europe 10 (4), 366-83.

2019 'The Swedish Condition': Representations of Religion in the Swedish Press 1988-2018. Temenos: Nordic Journal of Comparative Religion 55 (2), 271-92.

\section{Lövheim, Mia and Liv Ingeborg Lied}

2018 Approaching Contested Religion. - Knut Lundby (ed.), Contesting Religion: The Media Dynamics of Cultural Conflicts in Scandinavia, 65-78. Berlin: De Gruyter.

\section{Lövheim, Mia and Alf Linderman}

2015 Religion, Media and Modernity: Editorials and Religion in Swedish Daily Press. - Titus Hjelm (ed.), Is God Back? Reconsidering the New Visibility of Religion, 32-45. London: Bloomsbury.

\section{Lövheim, Mia and Knut Lundby}

2013 Mediated Religion across Time and Space. A Case Study of Norwegian Newspapers. Nordic Journal of Religion and Society 26 (1), 25-44.

\section{Michelsen, Jaran Ree}

2016 Islam dominerer religionsdebatten. Vårt Land 17.08.2016.

\section{Østby, Lars and Anne Berit Dalgard}

2017 Det religiøse mangfoldet. 4 prosent muslimer i Norge? Oslo: Statistics Norway. 


\section{Retriever}

2017 Islam og muslimer i norske medier 2016. Oslo: Retriever/Fritt Ord.

\section{Slaatta, Tore}

2015 Print versus Digital in Norwegian Newspapers. Media, Culture $\mathcal{E}$ Society 37 (1), 124-33.

\section{Syvertsen, Trine, Gunn Enli, Ole J. Mjøs, and Hallvard Moe}

2014 The Media Welfare State: Nordic Media in the Digital Era. Ann Arbor: The University of Michigan Press.

\section{Taira, Teemu}

2019a Studying Religion in Nordic Newspapers: An Introduction. Temenos: Nordic Journal of Comparative Religion 55 (2), 175-99.

2019b From Lutheran Dominance to Diversity: Religion in Finnish Newspapers 1946-2018. Temenos: Nordic Journal of Comparative Religion 55 (2), 225-47.

\section{van Dijck, José \& Thomas Poell \& Martijn de Waal}

2018 The Platform Society: Public Values in a Connective World. Oxford: Oxford University Press. 